\title{
INTEGRITAS ILMU DALAM PERPEKSTIF PENDIDIKAN
}

\author{
Rokhis Setiawati \\ SMA Bae Kudus, Jawa Tengah, Indonesia \\ rokhissetiawati@gmail.com
}

\begin{abstract}
SCIENCE INTEGRITY IN EDUCATION PERSPECTIVE. The advance of science and technology makes the life increasingly easy and simple for some communities. Academic discourse on character education in Indonesia is getting crowded to discusssince the character education movement launched on May 2, 2010.This discourse emerged and developed related to the development of science and technology that only put forward only its material aspect without balanced with the development and construction of its spiritual aspect. The purpose of this study was to determine the integrity of general science and religious studies in an educational perspective that emphasizes on character education in the world of education that leads to a private establishment that excel in science and technology in accordance with the demands of erabut not lost identity and character, on the basis faith and piety to God Almighty. The emphasis on nation-building and nation-character became one of the priorities of education today, which is based on the planting and understanding of the religious science and nationality. Based on the explanation above, the integration efforts of public education with Islamic values cannot be separated from the universality of knowledge that should be applied in the learning process without promoting independence (searching for differences) science.
\end{abstract}

Keywords: Science Integrity, Character Education, Character. 


\begin{abstract}
Abstrak
Kemajuan ilmu pengetahuan dan teknologi menjadikan hidup bagi sebagian masyarakat kita dirasakan semakin mudah dan sederhana. Wacana akademik mengenai pendidikan karakter di Indonesia semakin ramai dibahas sejak dicanangkannya gerakan pendidikan karakter pada tanggal 2 Mei 2010. Wacana ini muncul dan berkembang terkait dengan perkembangan ilmu dan teknologi yang hanya mengedepankan aspek materialnya saja tanpa diimbangi dengan perkembangan dan pembangunan aspek spiritualnya. Tujuan dari penelitian ini adalah untuk mengetabui integritas ilmu umum dan ilmu agama dalam perspektif pendidikan yang menekankan pada pendidikan karakter dalam dunia pendidikan yang mengarah pada pembentukan pribadi yang unggul dalam ilmu pengetabuan dan teknologi sesuai dengan tuntutan jaman tetapi tidak bilang jati diri dan karakternya serta dilandasi dengan iman dan taqwa kepada Tuhan Yang Maha Esa. Penekanan pada pembentukan bangsa dan karakter bangsa (nation and character building) menjadi salah satu prioritas pendidikan saat ini, yang dilandasi dengan penanaman dan pemahaman ilmu agama dan kebangsaan. Berdasarkan uraian di atas, upaya terintegrasinya pendidikan umum dengan nilai-nilai islami tidak terlepas dari universalitas keilmuan yang harus diterapkan dalam proses pembelajaran tanpa mengedepankan independensi (mencari-cari perbedaan) keilmuan.
\end{abstract}

Kata Kunci: Integritas Ilmu, Pendidikan Karakter, Karakter

\title{
A. Pendahuluan
}

Perkembangan ilmu dan teknologi dari waktu ke waktu terus mengalami perkembangan dan kemajuan yang pesat, seiring dengan tingkat berpikir manusia. Dari tahapan yang paling mitis, pemikiran manusia terus berkembang hingga sampai pada yang supra rasional. Dalam konteks ini, negara kita Indonesia termasuk negara yang menempati posisi terbesar jumlah penduduk muslimnya. Tetapi potensi mayoritas muslim tersebut belum menjamin peran sosialnya. Hal ini tentu saja terkait dengan soal konseptualisasi ilmu dan pendidikan. Hal tersebut terkait dengan pendidikan mental dan spiritual yang terintegrasi dengan pendidikan umum. 
Di lingkungan pendidikan penerimaan dan pencarian informasi tersebut dapat diperoleh melalui proses pembelajaran di sekolah sehingga ilmu yang diajarkan dalam agama dianggap sebagai suatu kebutuhan dan kepentingan sehingga memunculkan rasa ingin tahu dan terwujudlah integritas ilmu dan agama yang membentuk kepribadian yang matang dengan karakter kuat.

Kemajuan ilmu pengetahuan dan teknologi menjadikan hidup bagi sebagian masyarakat kita dirasakan semakin mudah dan sederhana. Namun di sisi lain kemudahan dan kesederhanaan tersebut menimbulkan krisis dalam kehidupan antara lain adalah pola hidup yang konsumtif dan individualis serta krisis moral yang jauh dari nilai agama. Masyarakat cenderung mengejar kehidupan yang bersifat fisik dan mengabaikan nilai-nilai moral dan budaya yang ada. Fenomena tersebut dapat dilihat dengan maraknya kehidupan yang jauh dari nilai-nilai agama dengan pola sekulerisme. " kalau umat Islam dan orang barat sudah samasama memegangi dan melaksanakan integritas dan aplikasi ilmu menurut kehendak Allah itu barulah krisis-krisis yang melanda kehidupan mereka dapat mereka atasi”.

Manusia baru akan mencapai kesejahteraan apabila ia sudah mengintegritaskan ilmu pengetahuan dan ajaran agama di dalam segala pemikiran dan tindakannya". Integritas ilmu dan agama merupakan solusi dari pandangan yang ekstrim dari ilmuan tentang tidak dipisahkannya ilmu agama dan ilmu umum. ${ }^{2}$ Namun, solusi ini masih menyisakan masalah yaitu harapan dan tantangan tentang integritas ilmu dan agama dalam pendidikan di Indonesia dalam rangka membentuk pribadi yang berkarakter. Dalam perkembangannya ada sebagian kalangan yang masih belum dapat menerima integritas ilmu dan agama ini sebagai satu kesatuan yang bersifat aplikatif. Integritas ilmu dan agama yang baik diharapkan akan membentuk kepribadian dan karakter yang

\footnotetext{
${ }^{1}$ Syahminan Zaini, Integrasi Ilmu dan Aplikasinya menurut al-Quran. (Jakarta: Kalam Mulia, 2009), hlm. 89.

${ }^{2}$ Ibid., 78
} 
kuat sebagai bagian dan modal dalam membangun bangsa. Proses pembentukan kepribadian dan karakter tersebut salah satunya melalui pendidikan dengan pendidikan karakter yang terintegrasi dalam pendidikan di sekolah dalam setiap mata pelajaran.

Seiring dengan tumbuh kembangnya seorang anak, tentunya banyak pihak yang mempengaruhinya. Pertama dalam lingkungan keluarga, lingkungan pendidikan, lingkungan agama, dan lingkungan pergaulan. Dalam hal ini, fokus permasalahannya akan membahas pada lingkungan pendidikan, yang berfokus dengan pendidikan karakter dan pendidikan Islam. Pendidikan merupakan suatu kegiatan yang melibatkan dua pihak sekaligus. Pihak pertama subjek pendidikan, yaitu pihak yang melaksanakan pendidikan, sedang pihak kedua adalah objek pendidikan, yaitu pihak yang menerima pendidikan.

Wacana akademik mengenai pendidikan karakter di Indonesia semakin ramai dibahas sejak dicanangkannya gerakan pendidikan karakter pada tanggal 2 Mei 2010. Wacana ini muncul dan berkembang terkait dengan perkembangan ilmu dan teknologi yang hanya mengedepankan aspek materialnya saja tanpa diimbangi dengan perkembangan dan pembangunan aspek spiritualnya. Sosok pendidikan karakter di Indonesia khususnya di lingkunagan pendidikan dewasa ini setidaknya dapat kita ketahui dengan telah terbitnya buku Pengembangan Pendidikan Budaya dan Karakter Bangsa, Bahan Pelatihan Penguatan Metodologi Pembelajaran Berdasarkan Nilai-Nilai Budaya untuk Membentuk Daya Saing dan Karakter Bangsa terbitan Pusat Kurikulum, Kementrian Pendidikan nasional Tahun 2010.

Tujuan dari pembahasan ini adalah untuk mengetahui integritas ilmu umum dan ilmu agama dalam perspektif pendidikan yang menekankan pada pendidikan karakter dalam dunia pendidikan yang mengarah pada pembentukan pribadi yang unggul dalam ilmu pengetahuan dan teknologi sesuai dengan tuntutan jaman tetapi tidak hilang jati diri dan karakternya serta dilandasi dengan iman dan taqwa kepada Tuhan Yang Maha Esa. 


\section{B. Pembahasan}

\section{Integritas Ilmu}

Integritas Ilmu yang akan dibahas dalam tulisan ini adalah integritas ilmu agama dan ilmu umum. Integritas ilmu agama dan ilmu umum hakikatnya adalah usaha menggabungkan atau menyatupadukan ontologi, epistemologi dan aksiologi ilmuilmu pada kedua bidang tersebut. Integritas kedua ilmu tersebut merupakan sebuah keniscayaan tidak hanya untuk kebaikan umat islam semata, tetapi bagi peradaban umat manusia seluruhnya. Karena dengan integritas ilmu akan jelas arahnya, yakni mempunyai ruh yang jelas untuk selalu mengabdi pada nilai-nilai kemanusiaan dan kebajikan jagat raya, bukan malah menjadi alat dehumanisasi, eksploitasi, dan destruksi alam. Nilai-nilai itu tidak bisa tercapai bila dikotomi ilmu masih ada seperti yang terjadi saat ini. Ilmu merupakan istilah yang memiliki beragam makna.

Menurut The Liang Gie ilmu dapat dibedakan menurut cakupannya. Pertama, ilmu merupakan sebuah istilah umum untuk menyebut segenap pengetahuan ilmiah yang dipandang sebagai satu kebulatan. Dalam arti yang pertama ini ilmu mengacu pada ilmu pada umumnya. Adapun dalam arti yang kedua ilmu menunjuk pada masing-masing bidang pengetahuan ilmiah yang mempelajari satu pokok soal tertentu misalnya antropologi, geografi, sosiologi. Tulisan ini menempatkan pemahaman ilmu pada arti yang pertama.

Ilmu dapat pula dibedakan berdasarkan maknanya, yaitu pengetahuan, aktivitas dan metode. Dalam arti pengetahuan, dikatakan bahwa ilmu adalah suatu kumpulan yang sistematis dari pengetahuan (any systematic body of knowledge). John G. Kemeny menggunakan istilah ilmu dalam arti semua pengetahuan yang dihimpun dengan perantaraan metode ilmiah. (all knowlwdge collected by means of the scientific method). Ilmu dalam bahasa Arab berasal dari kata 'alima yang berarti 'tahu'. Dalam bahasa Inggris di sebut science berasal dari perkataan Latin scientia yang 
diturunkan dari kata scire yang berarti mengetahui (to know) atau belajar (to learn). Dalam arti yang kedua ini ilmu dipahami sebagai aktifitas, sebagaimana dikatakan Charles Singer bahwa ilmu adalah proses yang membuat pengetahuan (science in the process which makes knowledge).

Sebagai aktifitas, ilmu melangkah lebih lanjut pada metode. Titus mengatakan bahwa banyak orang mempergunakan istilah ilmu untuk menyebut suatu metode guna memperoleh pengetahuan yang objektif dan dapat membuktikan kebenarannya (a method of obtaining knowledge that is objective and verifiable). Pengertian Agama Dalam Musyawarah Antar Agama di Jakarta, 30 November 1967, terkait dengan agama, H.M. Rasjidi mengatakan bahwa agama adalah hal yang disebut sebagai problem of ultimate concern, oleh karenanya tidak mudah untuk didefinisikan. Mukti Ali menunjukkan tiga alasan mengapa agama sulit didefinisikan, yaitu pertama, pengalaman keagamaan bersifat batiniah dan subjektif. Kedua, membahas arti agama selalu melibatkan emosi. Ketiga, arti agama dipengaruhi oleh tujuan orang yang memberikan pengertian agama tersebut.

Agama secara etimologis berasal dari bahasa Arab "aqoma" yang berarti 'menegakkan'. Sementara kebanyakan ahli mengatakan bahwa kata 'agama' berasal dari bahasa Sanskerta, yaitu $a$ (tidak) dan gama (berantakan), sehingga agama berarti tidak berantakan. Namun ada pula yang mengartikan $a$ adalah cara dan gama berarti jalan. Agama berarti cara-cara berjalan untuk samapai kepada keridhaan Tuhan. Selain dua pandangan tersebut, kata 'agama' sering disejajarkan dengan kata majemuk "negara kertagama" yang berarti peraturan tentang kemakmuran agama, atau juga dengan kata majemuk "asmaragama" yang berarti peraturan tentang asmara, dengan kata lain agama dalam hal ini dapat diartikan peraturan atau tata cara.

Agama yang dalam bahasa Inggris, Perancis dan Jerman disebut religion atau dalam bahasa Belanda disebut religie, diambil dari bahasa Latin, yaitu relege (to treat carefully), relegare (to bind 
together) dan religare (to recover). Dalam Islam 'agama' disebut dengan 'dien' yang oleh Moenawar Chalil dijelaskan bahwa: "Kata dien itu mashdar dari kata kerja daana - yadienu. Menurut lughat, kata dien itu mempunyai arti bermacam-macam, antara lain berarti: 1) cara atu adat istiadat, 2)peraturan, 3) undangundang, 4) taat atau patuh, 5) menunggalkan ketuhanan, 6) pembalasan, 7) perhitungan, 8) hari kiamat, 9) nasihat, 10) agama." Dalam Filsafat Perennial, agama memiliki dimensi eksoterik (bentuk) dan esoterik (substansi). Secara eksoterik di dunia ini dikenal banyak agama, namun diantara keragaman agama tersebut setiap agama memiliki substansi yang menjadi titik temu bagi keragaman tersebut. Agama yang dimaksud dalam tulisan ini secara eksoterik adalah Islam, namun secara esoterik tentu Islam memiliki nilai-nilai universal yang juga ada setiap agama

Integritas ilmu bukan hanya tuntutan zaman, tetapi mempunyai legitimasi yang kuat secara normatif dari Al-Qur'an dan Hadis serta secara historis dari perilaku para ulama Islam yang telah membuktikan sosoknya sebagai ilmuan integratif yang memberikan sumbangan luar biasa bagi kemajuan peradaban manusia.

\section{Pendidikan Karakter}

\section{a. Pengertian Pendidikan Karakter}

Secara umum, istilah karakter sering diasosiasikan dengan apa yang disebut dengan temperamen yang memberinya, seolah definisi yang menekankan unsur psikososial yang dikaitkan dengan pendidikan dan konteks lingkungan. Dari segi etimologi, karakter berasal dari bahasa Yunani yang berarti "to mark" atau menandai dan memfokuskan bagaimana mengaplikasikan nilai kebaikan dalam bentuk tindakan atau tingkah laku, sehingga orang yang tidak jujur, kejam, rakus dan perilaku jelek lainnya dikatakan orang berkarakter jelek. Sebaliknya, orang yang berprilaku sesuai dengan kaidah moral disebut dengan berkarakter mulia. Sedangkan dari segi istilah, karakter sering dipandang sebagai cara berfikir dan 
berperilaku yang menjadi ciri khas tiap individu untuk hidup dan bekerjasama, baik dalam lingkungan keluarga, masyarakat, bangsa dan negara. Individu yang berkarakter baik adalah individu yang bisa membuat keputusan dan siap mempertanggungjawabkan setiap akibat dari keputusan yang ia buat.

Pendidikan karakter adalah suatu sistem penanaman nilainilai karakter kepada warga sekolah yang meliputi komponen pengetahuan, kesadaran atau kemauan, dan tindakan untuk nilai-nilai tersebut. Pendidikan karakter pada hakekatnya ingin membentuk individu menjadi seorang pribadi bermoral yang dapat menghayati kebebasan dan tanggung jawabnya, dalam relasinya dengan orang lain dan dunianya dalam komunitas pendidikan. Dengan demikian pendidikan karakter senantiasa mengarahkan diri pada pembentukan individu bermoral, cakap mengambil keputusan yang tampil dalam perilakunya, sekaligus mampu berperan aktif dalam membangun kehidupan bersama.

\section{b. Tujuan Pendidikan Karakter}

Manusia secara natural memang memiliki potensi didalam dirinya. Untuk bertumbuh dan berkembang mengatasi keterbatasan manusia dan keterbatasan budayanya. Di pihak lain manusia juga tidak dapat abai dan tidak peduli terhadap lingkungan sekitarnya. Tujuan pendidikan karakter semestinya diletakkan dalam kerangka gerak dinamis diakletis, berupa tanggapan individu atau impuls natural (fisik dan psikis), sosial, kultural yang melingkupinya, untuk dapat menempa dirinya menjadi sempurna sehingga potensi-potensi yang ada dalam dirinya berkembang secara penuh yang membuatnya semakin menjadi manusiawi. Semakin menjadi manuusiawi berarti membuat ia juga semakin menjadi makhluk yang mampu berelasi secara sehat dengan lingkungan di luar dirinya tanpa kehilangan otonomi dan kebebasannya, sehingga ia menjadi manusia yang bertanggungjawab.

Pendidikan karakter lebih mengutamakan pertumbuhan moral individu yang ada dalam lembaga pendidikan. Untuk ini, 
dua paradigma pendidikan karakter merupakan suatu keutuhan yang tidak dapat dipisahkan. Peranan nilai dalam diri siswa dan pembaruan tata kehidupan bersama yang lebih menghargai kebebasan individu merupakan kedua wajah pendidikan karakter dalam lembaga pendidikan.

\section{c. Dasar Pembentukan Karakter}

Dasar pembentukan karakter itu adalah nilai baik atau buruk. Nilai baik disimbolkan dengan nilai Malaikat dan nilai buruk disimbolkan dengan nilai Setan. Karakter manusia merupakan hasil tarik-menarik antara nilai baik dalam bentuk energy positif dan nilai buruk dalam bentuk energi negatif. Energi positif itu berupa nilai-nilai etis religius yang bersumber dari keyakinan kepada Tuhan, sedangkan energi negatif itu berupa nilai-nilai yang a-moral yang bersumber dari taghut (Setan).

Nilai-nilai etis moral itu berfungsi sebagai sarana pemurnian, pensucian dan pembangkitan nilai-nilai kemanusiaan yang sejati (hati nurani). Energi positif itu berupa: Pertama, kekuatan spiritual. Kekuatan spiritrual itu berupa îmân, islâm, ihsân dan taqwa, yang berfungsi membimbing dan memberikan kekuatan kepada manusia untuk menggapai keagungan dan kemuliaan (ahsani taqwim); Kedua, kekuatan potensi manusia positif, berupa âqlus salîm (akal yang sehat), qalbun salîm (hati yang sehat), qalbun munîb (hati yang kembali, bersih, suci dari dosa) dan nafsul mutmainnah (jiwa yang tenang), yang kesemuanya itu merupakan modal insani atau sumber daya manusia yang memiliki kekuatan luar biasa. Ketiga, sikap dan Perilaku etis. Sikap dan perilaku etis ini merupakan implementasi dari kekuatan spiritual dan kekuatan kepribadian manusia yang kemudian melahirkan konsep-konsep normatif tentang nilai-nilai budaya etis. Sikap dan perilaku etis itu meliputi: Istiqâmah (integritas), ihlâs, jihâd dan amal saleh.

Energi positif tersebut dalam perspektif individu akan melahirkan orang yang berkarakter, yaitu orang yang bertaqwa, memiliki integritas (nafs al-mutmainnah) dan beramal saleh. 
Aktualisasi orang yang berkualitas ini dalam hidup dan bekerja akan melahirkan akhlak budi pekerti yang luhur karena memiliki personality (integritas, komitmen dan dedikasi), capacity (kecakapan) dan competency yang bagus pula (professional).

Kebalikan dari energi positif di atas adalah energi negatif. Energi negatif itu disimbolkan dengan kekuatan materialistik dan nilai-nilai thâghût (nilai-nilai destruktif). Kalau nilai-nilai etis berfungsi sebagai sarana pemurnian, pensucian dan pembangkitan nilai-nilai kemanusiaan yang sejati (hati nurani), nilai-nilai material (thâghht ) justru berfungsi sebaliknya yaitu pembusukan, dan penggelapan nilai-nilai kemanusiaan. Hampir sama dengan energi positif, energi negatif terdiri dari:

Pertama, kekuatan thaghut. Kekuatan thâghût itu berupa kufr (kekafiran), munafiq (kemunafikan), fasiq (kefasikan) dan syirik (kesyirikan) yang kesemuanya itu merupakan kekuatan yang menjauhkan manusia dari makhluk etis dan kemanusiaannya yang hakiki (absani taqwîm) menjadi makhluk yang serba material (asfala sâfilîn);

Kedua, kekuatan kemanusiaan negatif, yaitu pikiran jabiliyah (pikiran sesat), qalbun marîdl (hati yang sakit, tidak merasa), qalbun mayyit (hati yang mati, tidak punya nurani) dan nafsu 'l-lawwamah (jiwa yang tercela) yang kesemuanya itu akan menjadikan manusia menghamba pada ilah-ilah selain Allah berupa harta, sex dan kekuasaan (thâghât).

Ketiga, sikap dan perilaku tidak etis. Sikap dan perilaku tidak etis ini merupakan implementasi dari kekuatan thâghût dan kekuatan kemanusiaan negatif yang kemudian melahirkan konsep-konsep normatif tentang nilai-nilai budaya tidak etis (budaya busuk). Sikap dan perilaku tidak etis itu meliputi: takabur (congkak), bubb al-dunyâ (materialistik), dlâlim (aniaya) dan amal sayyiât (destruktif).

Energi negatif tersebut dalam perspektif individu akan melahirkan orang yang berkarakter buruk, yaitu orang yang 
puncak keburukannya meliputi syirk, nafs lawwamah dan 'amal al sayyiât (destruktif). Aktualisasi orang yang bermental thâghût ini dalam hidup dan bekerja akan melahirkan perilaku tercela, yaitu orang yang memiliki personality tidak bagus (hipokrit, penghianat dan pengecut) dan orang yang tidak mampu mendayagunakan kompetensi yang dimiliki.

\section{d. Pendidikan Karakter dalam Pendidikan Islam}

Pendidikan karakter merupakan langkah penting dan strategis dalam membangun kembali jati diri individu maupun bangsa. Tetapi penting untuk segera dikemukakan bahwa pendidikan karakter harusah melibatkan semua pihak; rumahtangga dan keluarga; sekolah; dan lingkungan sekolah lebih luas (masyarakat). Karena itu, langkah pertama yang harus dilakukan adalah menyambung kembali hubungan dan educational network yang nyaris terputus antara ketiga lingkungan pendidikan ini.

Berdasarkan sebuah hadits yang diriwayatkan Anas r.a, keluarga yang baik memiliki empat ciri. Pertama, keluarga yang memiliki semangat (ghirah) dan kecintaan untuk mempelajari dan menghayati ajaran-ajaran agama dengan sebaik-baiknya untuk kemudian mengamalkan dan mengaktualitaskannya dalam kehidupan sehari-hari. Kedua, keluarga dimana setiap anggotanya saling menghormati dan menyayangi;saling asah dan asuh. Ketiga, keluarga yang dari segi nafkah (konsumsi) tidak berlebih-lebihan; tidak ngoyo atau tidak serakah dalam usaha mendapatkan nafkah; sederhana atau tidak konsumtif dalam pembelanjaan. Keempat, keluarga yang sadar akan kelemahan dan kekurangannya.

Pembentukan watak dan pendidikan karakter melalui sekolah, dengan demikian, tidak bisa dilakukan semata-mata melalui membelajaran pengetahuan, tetapi melalui penanaman atau pendidikan nilai-nilai.

Lingkungan masyarakat luas juga memiliki pengaruh besar terhadap keberhasilan penanaman nilai-nilai estetika 
dan etika untuk pembentukan karakter. Dari perspektif Islam, situasi kemasyarakatan dengan sistem nilai yang dianutnya, mempengaruhi sikap dan cara pandang masyarakat secara keseluruhan. Jika sistem nilai dan pandangan mereka terbatas pada "kini dan di sini", maka upaya dan ambisinya terbatas pada kini dan di sini pula. ${ }^{3}$

Dalam konteks itu, al-Qur'an dalam banyak ayatnya menekankan tentang kebersamaan anggota masyarakat menyangkut pengalaman sejarah yang sama, tujuan bersama, gerak langkah yang sama, solidaritas yang sama.

Tujuan pendidikan karakter semestinya diletakkan dalam kerangka gerak dinamis diakletis, berupa tanggapan individu atau impuls natural (fisik dan psikis), sosial, kultural yang melingkupinya, untuk dapat menempa dirinya menjadi sempurna sehingga potensi-potensi yang ada dalam dirinya berkembang secara penuh yang membuatnya semakin menjadi manusiawi. ${ }^{4}$

\section{Pengembangan Kepribadian Islam}

Dalam pengembangan kepribadian Islam, hal yang paling utama adalah pengembangan qalb (hati). Hati yaitu tempat bermuara segala hal kebaikan ilahiyah karena ruh ada didalamnya. Secara psikologis, hati adalah cerminan baik buruk seseorang. Rasululullah SAW bersabda:" ketahuilah bahwa dalam jasad terdapat mudghah yang apabila baik maka baik pula sluruh anggota tubuh dan apabila rusak maka rusaklah seluruh tubuh.ketahuilah bhwa mudghah itu qalb."( HR.Al Bukhari dari an nu'man bin basyir). Qalb jika dirawat dan dikembangkan potensinya,cahayanya akan melebihi sinar matahari. Ia akan menjadi obor sepanjang zaman. Pada pembahasan inilah hakikat pengembangan islam dan mengingat kedudukan hati yng begitu

${ }^{3}$ M. Qurais Shihab, Wawasan al-Qur'an, (Bandung: Mizan, 1996), hlm. 45.

${ }^{4}$ Doni Koesoema, Pendidikan Karakter di Era Global, (Jakarta: Grasindo, 2007), hlm. 23. 
penting, maka unsur pembuka (ladang subur) pembahasannya adalah pendekatan agama.

Pada tahap selanjutnya adalah pengembangan Jism fisik). Fisik adalah badan dan seluruh anggotanya dapat dilihat dan diraba serta memiliki panca indera sebagai alat pelengkap. Rasulullah saw bersabda : " mukmin yang kuat lebih baik dan lebih dicintai Allah dibandingkan mukmin yang lemah..." (HR. Muslim).

Untuk mengetahui hal-hal apa yang harus dilakukan selama hidup, maka berikut dikutip dari Al-Qur'an tahap-tahap penciptaan manusia.Allah swt. berfirman: "dan Sesungguhnya Kami telah menciptakan manusia dari suatu saripati (berasal) dari tanah. Kemudian Kami jadikan saripati itu air mani (yang disimpan) dalam tempat yang kokoh (rahim). Kemudian air mani itu Kami jadikan segumpal darah, lalu segumpal darah itu Kami jadikan segumpal daging, dan segumpal daging itu Kami jadikan tulang belulang, lalu tulang belulang itu Kami bungkus dengan daging. kemudian Kami jadikan Dia makhluk yang (berbentuk) lain. Maka Maha Sucilah Allah, Pencipta yang paling baik. Kemudian, sesudah itu, Sesungguhnya kamu sekalian benarbenar akan mati. Kemudian, Sesungguhnya kamu sekalian akan dibangkitkan (dari kuburmu) di hari kiamat." (QS. Al-Mu'minuun: 12-16) .

Ayat-ayat tersebut menginformasikan asal-usul manusia lengkap dengan batasan-batasan, yaitu dibatasi oleh tanah dari segi fisik dan dibatasi oleh kekuasaan Tuhan dari segi qalb. Manusia yang unggul adalah manusia yang mampu mengembangkan potensi fisik dan psikis. Mencegahnya dari hal-hal yang merusak dan mampu menyembuhkannya jika sudah terlanjur sakit. ${ }^{5}$

Sedangkan dampak dari rusak (sakit) nya qalb dan jism berdampak pada nafs (psikis). Psikis adalah jiwa, yaitu tempat yang memunculkan gejala yang teraktualisasi dalam bentuk

${ }^{5}$ M. Qurays Shihab, Perempuan, (Bandung: Mizan, 2010), hlm. 80. 
perilaku (amaliah). Jiwa bisa sehat, sakit, atau hanya sekedar terganggu, tergantung dari aspek mana yang paling dominan pengaruhnya. Pepatah arab mengatakan : "tingkah laku lahir itu menunjukkan tungkah laku batin”, artinya kondisi nafs dapat dilihat dari bagaimana seseorang berperilaku. Orang yang sedang cemas dan gelisah dapat dilihat dari raut wajahnya yang kusut. Orang yang sedang marah atau malu dapat dilihat dari matanya yang memerah dan sebagainya. Dengan demikian, pengembangan kepribadian merupakan suatu proses yang dinamis. Dalam proses tersebut sifat individu dan sifat lingkungan menentukan tingkah laku apa yang akan menjadi aktual dan terwujud.

\section{Dasar Etika Sosial}

Di dalam Islam manusia adalah sentral ajarannya, baik dalam hubungannya dengan Tuhan, hubungan antar sesama manusia maupun antara manusia dan alam. Yang paling kompleks adalah yang kedua, yaitu hubungan antar sesama manusia. Hubungan manusia dengan Tuhannya adalah hubungan antara si makhluk dengan khaliknya. Jelas ada subordinasi ; si makhluk tunduk dan patuh terhadap sang Khalik. ${ }^{6}$ Hubungan antara manusia dengan alam (hewan, tumbuh-tumbuhan, bumi, laut, dan lainnya) adalah hubungan antara penerima amanat sebagai pengelola dengan penerima amanat sebagai yang dikelola: subyek dan obyek. Sedangkan untuk hubungan antar manusia dengan manusia tidak sama dengan kedua bentuk hubungan itu. Untuk itu, Islam mengajarkan konsep-konsep mengenai kedudukan, hak, dan kewajiban serta tanggung jawab manusia. Akibat dari apa yang dilakukan oleh setiap manusia bukan saja mempunyai nilai dan konsekuensi di dunia namun sekaligus juga di akhirat.

Konsep pertanggungjawaban di akhirat ini merupakan ciri khas konsep agama. Karena bagaimanapun canggih administrasi, tidak akan pernah terjadi tuntutan tanggung jawab di akhirat.

${ }^{6}$ Tatanan aturan kehidupan antara manusia yang selaras dengan akhlak yang telah di contohkan oleh Rosulluah, yang meliputi hubungan antara manusia dengan manusia dan dengan sang pencipta. 
Apapun yang telah di kerjakan, sebagai hal yang baik atau buruk, akan diketahui di akhirat kelak, dan akan dipertanggung jawabkan. Jika hal itu baik, maka pahala yang akan menjadi imbalannya, sedangkan jika hal itu buruk, maka akan ada tuntutan pertanggung jawabannya atas perbuatan buruknya itu.

\section{Hakikat Manusia}

Hakikat manusia adalah makhluk (manusia) ciptaan Tuhan. Hakekat wujudnya bahwa manusia adalah makhluk yang perkembangannya dipengaruhi oleh pembawaan dan lingkungan. Manusia yang sempurna adalah manusia yang sehat serta kuat dan berketrampilan cerdas serta pandai baik di lihat dari aspek fisik dan mentalnya. Perkembangan ilmu dan teknologi yang semakin pesat ternyata memabawa dampak baik positif maupun negatif. Terlihat jelas bahwa saat ini sedang terjadi krisis moral dan kepribadian. Krisis ini salah satunya adalah pondasi ilmu agama yang tidak kuat di tengah-tengah perkembangan teknologi yang sangat cepat.

Degradasi moral yang terjadi sekarang ini memunculkan keprihatinan dari banyak pihak. Banyak usaha yang sudah dilakukan baik itu secara mandiri melalui organisasi sosial/ pendidikan non formal maupun secara terintegrasi melalui pendidikan formal yang dikukuhkan dalam penyempurnaan Kurikulum di satuan pendidikan mulai dari KBK (Kurikulum Berbasis Kompetensi) tahun 2004, KTSP (Kurikulum Tingkat Satuan Pendidikan) tahun 2006 dan penyempurnaan yang terakhir dengan Kurikulum 2013 yang mengintegrasikan pendidikan agama dan karakter dalam setiap mata pelajaran.

Usaha ini dilakukan dalam rangka menghadapi tantangan dunia global yang semakin maju bahwa kesiapan kita sebagai bangsa tidak hanya dalam hal ilmu dan teknologi semata, tetapi diimbangi dan dikuatkan dengan kesiapan moral dan landasan ilmu agama yang kuat agar kita tidak tergelincir dalam arus modernisasi yang sekuler. Kekuatan ilmu agama diharapkan 
akan menjadi benteng arus globalisasi tersebut sehingga ditengah-tengah perkembangan ilmu dan teknologi yang cepat bangsa kita masih mampu bersaing dengan kekuatan moral dan karakter bangsa yang kuat sehingga tidak kehilangan jati dirinya sebagai bangsa.?

Penekanan pada pembentukan bangsa dan karakter bangsa (nation and character building) menjadi salah satu prioritas pendidikan saat ini yang dilandasi dengan penanaman dan pemahaman ilmu agama dan kebangsaan. Indonesia yang sebagian besar masyarakatnya adalah muslim, pembentukan nilai dan karakter ini lebih banyak mengadopsi pada ajaran yang ada pada agama Islam. Yang jelas terlihat secara kuantitatif adalah bahwa dalam pendidikan formal dengan Kurikulum 2013 nya , untuk mata pelajaran Pendidikan Agama jumlah jam tatap mukanya bertambah dari 2 jam pelajaran setiap minggunya menjadi 3 jam pelajaran setiap minggu. Mata pelajaran PKn (Pendidikan Kewarganegaraan) juga ditambah dari 2 jam pelajaran menjadi 3 jam pelajaran setiap minggunya, disamping penanaman nilai-nilai yang terintegrasi dalam setiap mata pelajarannya. ${ }^{8}$

Langkah kuantitatif tersebut diambil karena beberapa fenomena yang terjadi dalam masyarakat kita sekarang ini. Beberapa hal yang menjadi catatan penulis adalah bahwa masyarakat kita mengarah pada kecenderungan-kecenderungan sebagai berikut:

a. Memudarnya Nasionalisme dan Jati Diri Bangsa. Dalam kehidupan berbangsa dan bernegara akhir-akhir ini terlihat bahwa semangat dan jiwa nasionalisme Indonesia semakin terkikis dan memudar. Hal ini bias dilihat dari pola hidup masyarakat yang mengarah pada individualism, hedonism,

\footnotetext{
${ }^{7}$ Armahedi Mahzar, Revolusi Integralisme Islam, (Bandung: Mizan, 2003), hlm. 54 .

${ }^{8}$ Kemendiknas, Kebijakan nasional Pembangunan Karakter Bangsa. (Jakarta: Kemendiknas. 2013), hlm. 45.
} 
terorisme dan bahkan sepatisme yang melanda hamper seluruh komponen bangsa. Contoh sederhana yang bias kita lihat adalah bahwa masyarakat lebih bangga menggunakan produk dalam negeri, ada sebagian dari masyarakat Indonesia yang menjadi anggota Wamil di Negara tetangga.

b. Merosotnya Harkat dan Martabat Bangsa. Indonesia adalah Negara yang besar. Kepaulauan terbesar di dunia, Negara dengan multi budaya, etnik, bahasa dan suku yang besar, memiliki warisan sejarah yang menakjubkan, kekayaan alam dan kuliner serta kreativitas anak bangsa yang luar biasa, yang sejatinya dapat dijadikan modal dalam persaingan dunia global. Namun kekayaan tersebut tertutupi oleh fenomena yang terjadi di masyarakat kita akhir-akhir ini seperti Negara banyak kasus korupsi, malas, sarang teroris dan sebaagainya.

c. Mentalitas bangsa yang buruk. Indonesia memiliki modal atau kekuatan yang besar untuk menjadi bangsa yang besar dan Negara yang kuat. Modal tersebut dapat kita lihat dari luas wilayah, jumlah penduduk, kekayaan alam, budaya, bahsa, ketaatan dalam menjalankan ajaran agama dan system pemerintahan Republik yang demokratis.namun, modal tersebut seakan tidak berarti karena mentalitas bangsa yang belum terbangun secara utuh dan berubah kearah yang lebih baik.

d. Krisis Multidimensional. Berbagai permasalahan yang muncul akhir-akhir ini seperti konflik di daerah masih sering mengedapankan cara kekerasan untuk penyesaiannya. Praktek korupsi yang semakin terorganisir, perkelahian pelajar, praktek demokrasi Pancasila yang cenderung pada liberalism dan ekstrim serta tindak kekerasan dan kejahatan lainnya, seakan bertabrakan dengan budaya dan nilai-nilai kepatutan sebagai Bangsa Timur dan Bangsa yang religious. Sebagai bangsa Muslim terbesar di dunia, Indonesia masih menghadapi berbagai persoalan antara lain masih ada sebagian umat Islam belum bisa menjadikan kehidupan berbangsa dan bernegara 
di Indonesia sebagai at home. Mereka belum bias menerima keberadaaan Negara Kesatuan Republik Indonesia yang berdasarkan Pancasila dan Undang-undang Dasar 1945.

Berbagai persoalan di atas kiranya patut menjadi bahan renungan kita bersama. Jika kita mau menggali lebih dalam lagi, masih banyak persoalan-persoalan yang dihadapi di negara ini. Persoalan-persoalan tersebut didukung oleh banyak hal diantaranya adalah keberadaan media massa yang dengan fulgar dan terang-terangan serta diulang-ulang oleh hampir semua stasiun TV dan juga surat kabar. Fenomena tersebut apabila kita renungkan menimbulkan keprihatinan yang mendalam terhadap kualitas generasi muda di masa depan, prihatin terhadap citra dan daya saing bangsa kita. Berbagai permasalahan tersebut diasumsikan bersumber dari krisis etika dan moral. System pendidikan yang ada sekarang ini adalah pendidikan yang syarat dengan muatan yang hanya mengejar aspek fisiknya saja, mengesampingkan dimensi moral.

Media yang paling ampuh untuk merubah mentalitas dan berbagai persoalan tersebut adalah lewat pendidikan dan keyakinan agama. Pendidikan yang mampu merubah mentalitas dan persoalan-persoalan tersebut adalah pendidikan yang dilaksanakan dengan sungguh-sungguh dan mendidik dengan sepenuh hati. Keyakinan agama juga besar pengaruhnya bagi mentalitas bangsa. Pendidikan agama diharapkan mampu menjadi media untuk menanamkan keimanan yang benar, ibadah yang benar dan akhlakul kharimah, sehingga akan menjadikan anak didik sebagai manusia terbaik dengan budi pekerti luhur dan mampu bersaing dalam dunia global dalam bidang ilmu dan teknologi.

Pada tataran pendidikan formal, pendidikan agama diharapkan dapat melaksanakan tugas pokok pendidikan agama yaitu membentuk siswa yang memiliki moralitas dan akhlak serta budi pekerti yang mulia. Pembangunan karakter bangsa pada hakekatnya adalah pembangunan umat agar masyarakat 
Indonesia memiliki karakater yang kuat, berkahlak mulia dan berbudi pekerti yang luhur. Tujuan dalam pendidikan ini adalah manusia yang ahli di bidang ilmu dan teknologi yang mempunyai akhlak budi pekerti yang luhur. Karakter yang kuat dibangun atas dasar pemahaman tentang hakikat dan struktur kepribadian manusia secara integral atau menyeluruh. Pengintegrasian ilmu pengetahuan dan agama ini diharapakan dapat membentuk manusia yang berkarakter taqwa yaitu manusia yang memiliki kecerdasan spiritual (spiritual quotient). Kecerdasan spiritual inilah yang seharusnya ditekankan dalam pendidikan. Usaha trsebut dapat dilakukan dengan penanaman nilai-nilai etis religious melalui keteladanan dari keluarga, sekolah dan masyarakat, penguatan terhadap pengamalan ibadah, penciptaaan lingkungan fisik dan sosial yang kondusif. Hal ini dimaksudkan jika anak sudah tertata kecerdasan spiritualnya, maka akan lebih mudah untuk menata aspek-aspek kepribadian lainnya. Kunci dari kecerdasan emosional (emotional quotient), kecerdasan memecahkan masalah (adversity quotient) dan kecerdasan intelektual (intellectual quotient) adalah peningkatan kecerdasan spiritual (spiritual quotient). Aktivitas pendidikan yang berbasis agama lebih banyak berhasil dalam membentuk kepribadian anak.

Keterpaduan, keserasian dan pencahayaan ruh terhadap qalbu, akal dan nafsu dan raga akan jelas memaksimalkan kecerdasan dan fungsi dari masing-masing kecerdasan. Dalam konteks tujuan pendidikan, hal ini akan mampu membentuk anak yang memilki kekokohan aqidah ( quwwatul aqidah), kedalaman ilmu (quwwatul ilmi), ketulusan dalam pengabdian (quwwatul ibadah) dan keluhuran pribadi (akhlakul karimah). Keterpaduan dan integritas ilmu dan agama di atas menunjukkan adanya metode pembelajaran yang menyeluruh dan terintegrasi. Pendidikan adalah bantuan untuk menyadarkan, membangkitkan, menumbuhkan, memampukan dan memberdayakan anak didik akan potensi fitrahnya. 
Sebenarnya metode pembelajaran yang digunakan di sekolah lebih banyak dan lebih bervariasi serta mengedepankan keterpaduan antara ilmu pengetahuan, teknologi dan agama. Tujuan pendidikan dan pengajaran (pembelajaran) haruslah mengacu pada tujuan akhir pendidikan yaitu terbentuknya anak yang berkarakter taqwa dan berakhlak budi pekerti yang luhur. Tujuan Pendidikan Nasioanl adalah berkembangnya potensi peserta didik agar menjadi manusia yang briman dan bertaqwa kepada Tuhan Yang Maha Esa, berakhlak mulia serta sehat jasmani, berilmu, cakap, kreatif dan mandiri dan menjadi warga Negara yang demokratis dan bertanggung jawab. Tujuan pendidikan nasional tersebut dapat terwujud jika akan sinkronisasi antara ilmu pengetahuan dan pendidikan agama yang baik. Diharapkan pada saat ulang tahun emas Indonesia di tahun 2045 semua anak kita menjadai genarasi yang unggul di dalam ilmu pengetahuan dan teknologi dan mempunyai kepribadian dan karakter yang luhur dengan iman dan taqwa.

\section{Integrasi nilai-nilai Pendidikan Islami pada Pembelajaran}

\section{a. Pentingnya Integrasi Nilai-nilai Islami pada Proses Belajar Mengajar}

Bertolak dari rumusan UU Sistem Pendidikan Nasional RI No. 20 tahun 2003 pasal 339, yang mengisyaratkan bahwa tujuan pendidikan Indonesia mengarahkan warganya kepada kehidupan yang beragama. Maka sebagai salah satu bentuk realisasi dari UU Sisdiknas tersebut, Integrasi adalah alternatif yang harus di pilih untuk menjadikan pendidikan lebih bersifat menyeluruh (integralholistik). Gagasan integrasi (nilai-nilai islami/ agama dan umum) ini bukanlah sebuah wacana untuk meraih simpatik akademik, melainkan sebuah kebutuhan mendesak yang harus dijalankan sebagai pedoman pendidikan yang ada, mengingat pendidikan selama ini dipengaruhi oleh dualisme yang kental antara ilmuilmu agama dan ilmu-ilmu umum/ sekuler yang menyebabkan dikotomi ilmu. 
Bukti nyata dari kebutuhan adanya panduan dan model integrasi ilmu ini ditunjukan dengan diselenggarakannya berbagai seminar nasional berkenaan dengan reintegrasi ilmu, sampai pada kebijakan dari pemerintah, seperti kebijakan integrasi madrasah ke dalam sistem pendidikan nasional dalam UUSPN No. 2 tahun 1989, madrasah mengalami perubahan "sekolah agama" menjadi "sekolah umum bercirikan khas Islam". Pengintegrasian madrasah ke dalam sistem pendidikan nasional menemukan titik puncaknya pada awal 2000, setelah Presiden RI ke-4 K.H. Abdurrahman Wahid yang mengubah struktur Kementrian Pendidikan dari "Departemen Pendidikan dan Kebudayaan menjadi "Departemen Pendidikan Nasional". Berdasarkan Hal itu Abdurrahman Wahid menggulirkan ide "Pendidikan Satu Atap" Sistem Pendidikan Nasional dan memiliki status serta hak yang sama. Inilah yang diharapkan dan mengakhiri dikotomi "Pendidikan Umum" dan "Pendidikan Islam".

Sejarah menunjukan sudah sejak lama sebelum Istilah Integrasi memposisikan diri dalam memberikan kerangka normatif Nilai-nilai Islami pada pembelajaran, sebelumnya bahkan sampai saat ini gagasan Islamisasi Sains menjadi Jargon yang mendapat sambutan luar biasa dari cendikiawan Muslim, mulai Al-Maududi 1930-an, S.H. Nasr, Naquib Al-Attas dan Ja'far Syaikh Idris tahun 1960-1970-an; Ismail Al-Faruqi tahun 1980-an; sampai pada Ziauddin Sardar. Islamisasi sains tersebut tidak lain adalah sebuah reintegrasi ilmu, dalam menangkal ilmu (sekuler) yang disertai isme-isme yang datang dari luar yang belum tentu sesuai dengan peredaran darah dan tarikan nafas yang kita anut, yang akhir-akhir ini dikenal istilah integrasi. Sebagai hasil kebutuhan tersebut, untuk tingkat Universitas, akademisi ataupun umum misalnya terbit buku Integrasi Ilmu; sebuah rekonstruksi holisitk karangan Mulyadi Kertanegara, yang diharapkan menjadi buku dasar untuk UIN walaupun masih bersifat umum. Melacak jejak Tuhan: Tafsir Islami atas Sains karangan Mehdi Golshani yang sekarang menjadi hak paten milik negara dan oleh Diknas 
diedarkan kelembaga pendidikan SMP dan SMA. Bahkan secara revolusioner Armahedi Mahzar menerbitkan Revolusi Integralisme Islam: 'Merumuskan Paradigma Sains dan Teknologi Islami', 2004. Inilah beberapa alasan mendasar pentingnya integrasi untuk diterapkan dalam pembelajaran.

Dalam lingkup mikro, masih minimnya panduan Integrasi Nilai-nilai Islami pada proses pembelajaran di sekolah baik model, metode, ataupun pendekatan pembelajaran, dirasa perlu (kalau bukan harus) untuk menginterpretasikan kembali seluruh materi pelajaran sekolah dengan muatan-muatan nilai yang Islami. Tujuan kurikulum pendidikan Islami tidak semata-mata mendorong anak didik untuk mampu berkomunikasi tanpa bimbingan orang lain dan sekaligus dapat memecahkan masalah dengan baik, akan tetapi lebih sebagai jiwa atau ruh dari pendidikan itu. Sebagaimana pendidikan yang diajarkan Rasulullah Muhammad saw., yang lebih mengutamakan akhlak bagi ummatnya "li utammima makarim alakblak".9.

Tujuan pendidikan nilai pada dasarnya membantu mengembangkan kemahiran berinteraksi pada tahapan yang lebih tinggi serta meningkatkan kebersamaan dan kekompakan interaksi atau apa yang disebut Piaget sebagai ekonomi interaksi atau menurut Oser dinyatakan dengan peristilahan kekompakan komunikasi. Tujuan pendidikan nilai tidak dapat tercapai tanpa aturan-aturan, indoktrinasi atau pertimbangan prinsipprisnip belajar. Namun sebaliknya, dorongan moral komponen pembentukan struktur itu sangat penting. Oleh karena itu, pendidik seharusnya tidak hanya sekedar membekali dan menjejali siswa dengan pengetahuan tentang tujuan serta analisis dari hubungan antara tujuan dengan alat. ${ }^{10}$ Kurikulum 2013 yang sedang dilaksanakan saat ini merupakan jawaban dari kegelisahan dan kegundahan bangsa yang melihat fenomena bahwa anak

${ }^{9}$ Armai Arief. Reformasi Pendidikan Islam. (Jakarta: CRSD Press, 2005), hlm. 43.

${ }^{10}$ W. Sumpeno, Integrasi Ilmu dengan Islam, (t.k: t.p, 1996), hlm. 35. 
hanya bias sebatas kognitifnya semata, tetapi dangkal dalam aspek sikap dan kepribadian serta ketrampilannya.

Pentingnya integrasi pendidikan nilai tersebut menjadi satu kerangka normatif dalam merumuskan tujuan pendidikan Islam sebagaimana diungkapkan Ali Asraf_bahwa tujuan pendidikan Islam: Pertama, mengambangkan wawasan spiritual yang semakin mendalam dan mengembangkan pemahaman rasional mengenai Islam dalam konteks kehidupan modern. Kedua, membekali anak didik dengan berbagai kemampuan pengetahuan dan kebajikan, baik pengetahuan praktis, kesejahteraan, lingkungan sosial, dan pembangunan nasional. Ketiga, mengembangkan kemampuan pada diri anak didik untuk menghargai dan membenarkan superioritas komparatif kebudayaan dan peradaban Islam di atas semua kebudayaan lain. Keempat, memperbaiki dorongan emosi melalui pengalaman imajinatif, sehingga kemampuan kreatif dapat berkembang dan berfungsi mengetahui norma-norma Islam yang benar dan yang salah. Kelima, membantu anak yang sedang tumbuh untuk belajar berpikir secara logis dan membimbing proses pemikirannya dengan berpijak pada hipotesis dan konsepkonsep pengetahuan yang dituntut. Keenam, mengembangkan, menghaluskan, dan memperdalam kemampuan komunikasi dalam bahas tulis dan bahasa latin (asing).

Pengejawantahan kurikulum yang terpadu pada proses pembelajaran, tentunya tidak terlepas dari bagaimana strategi belajar mengajar yang hendak disampaikan pada siswa, hal ini juga terkait dengan metode dan pendekatan apa yang harus di gunakan. Metode mengajar adalah cara-cara atau teknik yang digunakan dalam mengajar, misalnya; ceramah, tanya jawab, diskusi sosiodrama, demonstrasi, dan eksperimen. Pendekatan lebih menunjukan pada bagaimana kelas dikelola, misalnya secara individu, kelompok dan klasikal. Steategi pembelajaran menunjuk kepada bagaimana guru mengatur keseluruhan proses belajar 
mengajar, meliputi: mengatur waktu, pemenggalan penyajian, pemiliham ,etode, dan pemilihan pendekatan. ${ }^{11}$

Dengan mengetahui metode, pendekatan pembelajaran terpadu yang digunakan maka pada prosesnya dapat mencapai target dan tujuan "nilai" pendidikan yang diharapkan. Pendidikan nilai bertujuan untuk menentukan sikap atau tingkah laku seseorang. Atmadi (2001:82) mengungkapkan bahwa metode yang ditempuh untuk mencapai tujuan pendidikan nilai tersebut antara lain:

1. Metode menasihati (moralizing) yaitu metode pendidikan nilai di mana seorang pendidik secara langsung mengajarkan sejumlah nilai yang harus menjadi pegangan hidup peserta didik. Dalam metode ini pendidik dapat menggunakan khotbah, berpidato, memberi nasehat atau memberi instruksi kepada peserta didik agar menerima saja sejumlah nilai sebagai pegangan hidup.

2. Metode serba membiarkan (a laissezfaire attitude), yaitu metode pendidikan nilai dimana seorang pendidik memberi kesempatan seluas-luasnya kepada peserta didik untuk menentukan pilihan terhadap nilai-nilai yang ditawarkan oleh pendidik. Pendidik hanya memberikan penjelasan tentang nilai-nilai tanpa memaksakan kehendaknya sendiri bahwa nilai ini atau itu yang seharusnya dipilih oleh peserta didik tetapi setelah memberi penjelasan pendidik mempersilahkan peserta didik mengambil sikap sendiri-sendiri.

3. Metode Model (modelling) yaitu metode pendidikan nilai dimana seorang pendidik mencoba meyakinkan peserta didik bahwa nilai tertentu itu memang baik dengan cara memberi contoh dirinya atau seseorang sebagai model penghayat nilai tertentu, pendidik berharap peserta didik tergerak untuk menirunya.

${ }^{11}$ Murniati, Manajemen Stratejik: Peran Kepala Sekolah (Bandung: Cita Pustaka Media Perintis, 2008), hlm. 45. 
Proses penilaian merupakan proses yang utama dalam pengembangan nilai dalam pembelajaran. Barman (1997) dan Abdul Aziz (1996) mengemukan enam alternatif pendekatan bagi terjadinya proses valuing dalam pembelajaran antara lain pendekatan untuk pengembangan kognitif, penanaman nilai, perkembangan moral, kejelasan nilai-nilai (value clarificarion), belajar tindakan (action learning), dan analisis.

Pendekatan pengembangan kognitif akan lebih memberikan kesempatan pada siswa untuk mampu mengembangkan pola-pola penalaran yang lebih kompleks didasarkan pada seperangkat nilai. Pendekatan penanaman nilai lebih bersifat indoktrinasi dalam pengembangan nilai. Proses penanaman nilai dengan merupakan internalisasi nilai-nilai tertentu yang dimiliki guru dan masyarakat kepada diri anak atau mengubah nilai-nilai anak kearah nilai-nilai tertentu yang dikehendakinya. Penjelasan tentang perkembangan moral membantu anak mengembangkan penalaran moralnya. Kejelasan nilai-nilai memberikan kesempatan kepada anak untuk menyadari dan mengenal nilai-nilainya dan juga nilai orang lain, serta mengkomunikasikan secara terbuka nilainilai mereka. Tujuan utama pendekatan belajar tindakan ialah memberi kesempatan kepada anak untuk melakukan tindakantindakan yang sesuai dengan nilai-nilainya melalui permainan peran, simulasi, diskusi dan sebagainya. Pendekatan analisis menyediakan pengalaman belajar menggunakan pemikiran logis serta penyelidikan ilmiah untuk mengevaluasi isu-isu melalui diskusi, melakukan penyelidikan dan analisis kasus.

\section{b. Penerapan Integarasi Nilai-nilai Islami pada Pembe- lajaran}

Kurikulum pendidikan Islam sampai saat ini masih dihadapkan pada kesulitan untuk mengintegrasikan dua kutub paradigma keilmuan dualistik. Pada satu sisi, harus berhadapan dengan 'subjek-subjek sekuler', dan pada sisis lain, dengan 'subjek-subjek keagamaan'. Subjek-subjek yang dianggap sekuler biasanya terdiri dari jenis keilmuan umum seperti matematika, 
fisika, biologi, kedokteran, sosiologi, ekonomi, politik, botani, zoologi, dan sebagainya. Sementara subjek-subjek keagamaan terdiri dari jenis sains wahyu seperti Alquran, Alhadits, fiqh, teologi, tasawuf, tauhid, dan semacamnya. Dari dikotomi diatas, kurikulum pendidikan umum dan Kurikulum pendidikan Islam masih berada pada wilayahnya masing-masing, sehingga proses pembelajarannya bersifat parsial dan terfragmentasi antara sains wahyu ilahi dan sains-sains alam. Padahal, menurut terminologi filsafat Islam, Tuhan menurunkan Alquran-Nya dalam bentuk: Alquran yang tertulis (recorded qur'an), yaitu wahyu yang tertulis dalam lembaran buku yang dibaca oleh ummat Islam setiap hari: dan Alquran yang terhampar (created quran), yaitu alam semesta, jagat raya atau kosmologi ini.

Dalam pelaksanaannya memang mesti ada prioritas proses pembelajaran antara kedua jenis keilmuan di atas. Berangkat dari pola pikir integratif, yaitu menyatukan arti kehidupan dunia dan akhirat, maka pendidikan umum pada hakikatnya adalah pendidikan agama juga, begitu pula sebaliknya, pendidikan agama adalah juga pendidikan umum. Idealnya tidak perlu terjadi persoalan ambivalensi dan dikotomik dalam orientasi pendidikan Islam.. Perpaduan itu harus terjadi sebagai proses pelarutan dan bukan sebagai pencampuran biasa. Nilai-nilai Alquran dapat diaktualisasikan tidak dalam perwujudan rancangan sistem pendidikan saja, tetapi dalam langkah-langkah operasionalisasinya mesti berpedoman pada kaidah-kaidah Qurani, sesuai dengan kesatuan tiga serangkai perangkat tindak yakni motivasi cara tujuan.

Dengan adanya penyatuan ilmu/ sains dengan nilai-nilai ajaran Islam, persoalan dikotomi akan dapat dicarikan jalan keluarnya. Wawasan ilmu tidak lagi dipisahkan secara dikotomis dalam pembagian ilmu-ilmu 'agama' dan ilmu-ilmu 'umum, tetapi akan di bedakan (bukan dipisahkan) menjadi ilmu-ilmu yang menyangkut ayat-ayat tanziliyyah (ayat-ayat yang tersurat 
dalam Alquran/ hadits) dan ilmu tentang ayat kauniyah (ilmu pengetahuan tentang kealaman).

Secara umum, Kurikulum Pembelajaran yang terintegrasi dengan nilai-nilai Islami pun disusun mencakup seluruh wawasan keilmuan sehingga akan membawa konsekuensi-konsekuensi tertentu terhadap struktur, tujuan, materi dan institusi pendidikan yang disiapkan. Begitu pula secara spesifik strategi belajar mengajar termasuk model, metode dan pendekatan pembelajaran sebagaimana telah disebutkan beberapa bentuknya diatas akan menentukan arah pendidikan yang terintegarasi dan bernuansa Islami.

Secara spesifik, spesialisasi ilmu yang terdapat dalam proses pembelajaran setidaknya dapat diadaptasi berdasarkan pada kelompok mata pelajaran Kurikulum Baru (subdirektorat kurikulum 2006) yang masih dalam proses penggodokan, antara lain meliputi: agama dan akblak mulia; kewarganegaraan dan kepribadian; ilmu pengetahuan dan teknologi; estetika; Jasmani, olahraga dan kesehatan. Spesialisasi kelompok mata pelajaran tersebut diharapkan dapat terintegrasi dengan nilai-nilai islami dalam pembelajaran.

Seringkali kita memahami bahwa ilmu Allah itu terdiri dari ayat-ayat kauniyah dan ayat-ayat qouliyah, sebenarnya di dalam QS. Fushshilat (41): 53, mengisyaratkan adanya dua kategori ilmu yang berbeda yaitu ilmu mengenai cakrawala ("afaq") dan ilmu mengenai diri manusia (anfusibim).

"Kami akan memperlihatkan kepada mereka tanda-tanda kekuasaan Kami di segenap ufuk dan pada diri mereka sendiri".

Jadi, Menurut al-Quran ilmu itu bukannya dua macam, kauniyah (ilmu-ilmu alam, nomothettic) dan qouliyah (ilmu-ilmu theological), tetapi tiga macam. Katakan yang ketiga itu adalah nafsiyah. Kalau ilmu kauniyah berkenaan dengan hukum alam, ilmu qauliyah berkenaan dengan hukum Tuhan, dan ilmu nafsiyah berkenaan dengan makna, nilai dan kesadaran. Ilmu nafsiyah 
inilah yang disebut sebagai bumaniora (ilmu-ilmu kemanusiaan, beurmeneutic). Meskipun dalam bahasa arab ilmu nafsiyab ialah psikologi. Ketiga macam ilmu tersebut bersumber pada ilmu Allah sebagai satu-satunya sumber kebenaran mutlak, sehingga berbagai derivasi keilmuan merupakan satu kesatuan bukanlah sebuah dikotomi. Secara skematik ketiga macam ilmu (kauniyah, Qouliyah dan nafsiyah) dapat terintegrasi dengan kelompok mata pelajaran sebagai salah satu bentuk spesialisasi integrasi pendidikan islami dalam pembelajaran.

\section{Simpulan}

Berdasarkan uraian diatas, upaya terintegrasinya pendidikan umum dengan nilai-nilai islami tidak terlepas dari universalitas keilmuan yang harus diterapkan dalam proses pembelajaran tanpa mengedepankan independensi (mencari-cari perbedaan) keilmuan. Integrasi pendidikan islami tersebut antara lain:

Pertama; Keutuhan kerangka nilai islami pada setiap kelompok mata pelajaran terintegrasi secara menyeluruh (integralbolisitk). Dengan kata lain antara pelajaran umum dan agama terintegrasi dalam bentuk: common matter integrated with religious matter [mengintegrasikan materi pelajaran umum dengan materi pelajaran pendidikan agama] yakni nilai-nilai islami inklusif dalam penyampaian pelajaran umum atau sebaliknya religious matter integrated with common matter (mengintegrasikan materi pelajaran agama dengan mata pelajaran umum) yakni agama tidak mendeskriditkan ilmu-ilmu umum. Kelompok mata pelajaran yang harus terintegrasi dengan nilai-nilai Islami dalam pembelajaran tersebut antara lain: agama dan akblak mulia; kewarganegaraan dan kepribadian; ilmu pengetahuan dan teknologi; estetika; Jasmani, olahraga dan kesehatan.

Kedua: Keragaman model, metode dan pendekatan integrated (terpadu) dengan nilai-nilai islami sebagai kerangka normatif dapat dijadikan perspektif baru bagi para pendidik dalam melaksanakan proses pembelajaran. Sehingga pembelajaran 
mengarah pada proses leader (mampu memilih bola yang harus dijemput) dan manager (tahu bagaimana mengelola bola) tanpa terlepas dari kerangka nilai islami.

Ketiga: Keterpaduan penyelenggaraan pendidikan mengharuskan nilai-nilai pendidikan Islami pada pembelajaran di sekolah teraplikasikan secara integrated dengan kebutuhan masyarakat dan keluarga. Pada realitasnya integrasi pendidikan dapat menghapus pendidikan yang bersifat paradoks antara ketiga unsur tersebut sehingga berimplikasi terhadap peningkatan kualitas (nilai) tanggungjawab moral dan akhlak siswa. 


\section{DAFTAR PUSTAKA}

Arief, Armai, Reformasi Pendidikan Islam, Jakarta: CRSD Press, 2005.

Bagir, zainal Abidin dkk, Integrasi Ilmu dan Agama. Bandung: Mizan. 2009

Kemendiknas, Kebijakan nasional Pe,bangunan Karakter Bangsa, Jakarta: Kemendiknas, 2010.

Koesoema, Doni, Pendidikan Karakter di Era Global, Jakarta: Grasindo, 2007.

Mahzar, ArmahediRevolusi Integralisme Islam, Bandung: Mizan, 2003.

Muhammad Fajrin Mustafa. Harapan dan Tantangan Integrasi Ilmu dan Agama daengmeraja@yahoo-com, Published on Wednesday, April 04, 2012.

Shihab, M. Qurays, Perempuan, Bandung: Mizan, 2010.

Shihab. M Qurais, Wawasan al-Qur'an, Bandung: Mizan, 1996.

Syam, Nur. Menegaskan Integrasi Ilmu Agama dan Umum dalam http://nursyam: sunan_ampel.ac.id?p $=2638$ /31 desember 2011.

Zaini, Syahminan, Integrasi Ilmu dan Aplikasinya menurut al-Quran. Jakarta: Kalam Mulia, 2009. 